\title{
Effect of Cube Size, Polythene Gauge and Vacuum on Physical Characteristics of Minimally Processed Potato
}

\author{
P. Shireesha*, R. Rajya Lakshmi, M. Rajashekar and M. Paratpara Rao
}

Department of vegetable science, Horticultural College \& Research Institute, Dr. Y.S.R. Horticultural University, Venkataramannagudem, West Godavari, Andhra Pradesh., India

*Corresponding author

\section{A B S T R A C T}

\section{Keywords}

Minimal processing potatoes, Cube size, Polythene gauge,

Vacuum, Shelf life

Article Info

Accepted:

15 November 2018

Available Online:

10 December 2018
Minimal processing potatoes have some undesirable physiological consequences like enzymatic browning on cut surfaces. Storability is limited due to enzyme catalyzed browning reaction. The enzymatic action varies depending upon the cube size, different gauges of polythene and vacuum packaging. The aim this work was to study the effect of cube size, polythene gauge and vacuum on Physical characteristics of minimally processed potato. Among all the combinations, the potato cubes with $2 \mathrm{~cm}^{3}$ cube sizes, 200 gauge polythene bag and with vacuum packaging recorded lower physiological changes and having better shelf life compared to $1 \mathrm{~cm}^{3}$ cube sizes, 100 gauge polythene bag without vacuum packaging.

\section{Introduction}

Potato is a valued raw material for processing industry. The most popular processed products of potato are chips, french fries, powder, cubes, slices and starch. To be competitive in global potato trade, India needs to accelerate the development and diffusion of suitable quality enhancing technologies in the processing sector. The changing lifestyle of the people, especially working women and bachelors keeps them very busy and they do not have sufficient time for preparation of vegetable cut pieces to cook. Therefore minimally processed foods makes them easy to cook and cut short the time required for peeling, cutting, slicing, etc. Application of partial processing increases perishability due to increased metabolic activities and decompartmentalization of enzymes and substrates, this may cause browning, softening and off- flavor development (Watada et al., 1990). Potatoes are extremely sensitive to enzymatic browning. Research has also been done on MAP (including vacuum packaging) of fresh-cut potatoes with different treatments. About two week shelf-life for fresh-cut potatoes could be achieved by vacuum packaging after treating potatoes with antibrowning agents (Anderson and Zapsalis, 
1957). It is estimated that over 50 per cent losses in processed potato products occur as a result of enzymatic browning. Browning of peeled potatoes is perceived to be unaesthetic to consumers and processors. To enhance the shelf life of minimally processed potato stored under ambient conditions an investigation was carried out to study the effect of cube size, polythene gauge and vacuum on shelf life of minimally processed potato.

\section{Materials and Methods}

Potato tubers of variety Kufri jyothi was selected washed and peeled. Potato cubes of two different sizes $1 \mathrm{~cm}^{3}$ and $2 \mathrm{~cm}^{3}$, free from blemishes, physical injuries were selected and treated with $2 \%$ potassium metabisulphite for ten minutes. The cubes after treatment were shade dried to remove excess moisture adhering them. Then they were packed in two different gauges (100 and 200 guages) of packaging material with and without vacuum were implemented the treatments as follows:

$\mathrm{T}_{1}-\mathrm{C}_{1} \mathrm{P}_{1} \mathrm{~V}_{1}-1 \mathrm{~cm}^{3}$ cube packed in 100 gauge polyethylene bag with vacuum

$\mathrm{T}_{2}-\mathrm{C}_{1} \mathrm{P}_{1} \mathrm{~V}_{2}-1 \mathrm{~cm}^{3}$ cube packed in 100 gauge polyethylene bag without vacuum

$\mathrm{T}_{3}-\mathrm{C}_{1} \mathrm{P}_{2} \mathrm{~V}_{1}-1 \mathrm{~cm}^{3}$ cube packed in 200 gauge polyethylene bag with vacuum

$\mathrm{T}_{4}-\mathrm{C}_{1} \mathrm{P}_{2} \mathrm{~V}_{2}-1 \mathrm{~cm}^{3}$ cube packed in 200 gauge polyethylene bag without vacuum

$\mathrm{T}_{5}-\mathrm{C}_{2} \mathrm{P}_{1} \mathrm{~V}_{1}-2 \mathrm{~cm}^{3}$ cube packed in 100 gauge polyethylene bag with vacuum

$\mathrm{T}_{6}-\mathrm{C}_{2} \mathrm{P}_{1} \mathrm{~V}_{2}-2 \mathrm{~cm}^{3}$ cube packed in 100 gauge polyethylene bag without vacuum

$\mathrm{T}_{7}-\mathrm{C}_{2} \mathrm{P}_{2} \mathrm{~V}_{1}-2 \mathrm{~cm}^{3}$ cube packed in 200 gauge polyethylene bag with vacuum

$\mathrm{T}_{8}-\mathrm{C}_{2} \mathrm{P}_{2} \mathrm{~V}_{2}-2 \mathrm{~cm}^{3}$ cube packed in 200 gauge polyethylene bag without vacuum

The above samples were evaluated everyday until end of shelf life.

The detailed observations on change in physiological parameters viz., Physiological loss in weight (PLW), change in colour, firmness, spoilage (\%) and organoleptic score were recorded daily during entire storage period. The potato cubes were assessed for change in colour every day up to end of storage period by following a subjective visual colour score.

\begin{tabular}{|l|l|}
\hline Point/Score & \multicolumn{1}{|c|}{ Colour } \\
\hline 1 & No change \\
2 & Light brown \\
3 & Dark brown \\
4 & Black \\
\hline
\end{tabular}

The organoleptic or the sensory evaluation of potato cubes was carried out by a panel of 5 judges following hedonic rating system for characters like aroma taste as per the score (51) described below (Sandhu and Parwhawk, 2002).

\begin{tabular}{|l|l|}
\hline Point/Score & Quality \\
\hline 1 & Very poor \\
2 & Poor \\
3 & Fair \\
4 & Good \\
5 & Excellent \\
\hline
\end{tabular}

\section{Results and Discussion}

Gradual increase was observed in physiological weight loss with increased duration of storage. Among the treatments potato cubes $T_{7}\left(2 \mathrm{~cm}^{3}\right.$ cube packed in 200 gauge polyethylene bag with vacuum) recorded lower PLW, this might be due to reduced transpiration rate, respiration activity because of higher thickness of polyethylene films. This could be because of lower permeability of higher gauge polyethylene (200 gauges LDPE) Sagar and Roy (1997).

Among the treatments, lowest colour score was observed in $\mathrm{T}_{7}\left(2 \mathrm{~cm}^{3}\right.$ cube packed in 200 gauge polyethylene bag with vacuum). As 
the days of storage progressed, the colour score increased at ambient conditions. Vacuum plays a major role in change in colour. The lightness factor of vacuum packed potatoes was almost constant in vacuum packaging compared to potatoes packed without vacuum. Therefore the potato cubes packed with vacuum showed lowest score which represents light brown colour. Similar results were found in Desiree variety of potato by Rocha et al., (2003).

The per cent spoilage was increases with storage period, Spoilage among the treatments more or less similar, however less spoilage was observed $\mathrm{T}_{7}\left(2 \mathrm{~cm}^{3}\right.$ cube packed in 200 gauge polyethylene bag with vacuum) spoilage was occurred in terms of colour change and microbial contamination. Brackett (1987) reported that minimal processing, leads to destruction of surface tissues during preparatory stages which exposes cytoplasm and provides a potentially richer sources of nutrients for the microorganisms than intact produce. This along with the water activity facilitates microbial growth in minimally processed fruits and vegetables (Table 1).

A decrease in firmness with increase in storage period was observed from the data. However, decrease in firmness was low in the treatment $\mathrm{T}_{7}\left(2 \mathrm{~cm}^{3}\right.$ cube packed in 200 gauge polyethylene bag with vacuum). This might be due to slower enzyme catalysed reactions causing less de polymerization of cell walls and less production of enzymes like inverterase and polygalacturonse that contribute to loss of texture. Similar results were observed by Balasubramanyam and Anandswamy (1979) who opined that potato chips packed in 200 gauge and 300 gauge polyethylene bags maintained better texture as compared to produce packed in lower gauge polypacks (Fig. 1).

Table.1 Effect of cube size, polythene gauge and vacuum on physical characteristics of potato cubes at the end of storage

\begin{tabular}{|c|c|c|c|c|c|}
\hline Treatment & $\begin{array}{c}\text { PLW } \\
(\%)\end{array}$ & $\begin{array}{c}\text { Change in } \\
\text { colour }\end{array}$ & $\begin{array}{c}\text { Firmness } \\
\text { cm- }^{2} \text { ) }\end{array}$ & Spoilage (\%) & $\begin{array}{c}\text { Shelflife } \\
\text { (days) }\end{array}$ \\
\hline $\mathrm{T}_{1}$ & 3.12 & 2.33 & 6.36 & 5.42 & 1.55 \\
\hline $\mathrm{T}_{2}$ & 4.11 & 2.66 & 3.16 & 7.26 & 1.33 \\
\hline $\mathrm{T}_{3}$ & 2.28 & 2.33 & 6.80 & 5.39 & 1.66 \\
\hline $\mathrm{T}_{4}$ & 3.37 & 2.33 & 3.16 & 5.05 & 1.44 \\
\hline $\mathrm{T}_{5}$ & 2.89 & 2.33 & 6.20 & 4.71 & 1.77 \\
\hline $\mathrm{T}_{6}$ & 3.38 & 2.33 & 3.03 & 5.65 & 1.55 \\
\hline $\mathrm{T}_{7}$ & 1.87 & 2.00 & 7.03 & 4.63 & 1.88 \\
\hline $\mathrm{T}_{8}$ & 3.81 & 2.33 & 4.00 & 5.02 & 1.55 \\
\hline $\mathrm{C} . \mathrm{D}$ at $5 \%$ & 0.225 & 0.024 & 0.034 & 0.334 & 0.035 \\
\hline $\mathrm{SE}(\mathrm{m}) \pm$ & 0.065 & 0.020 & 0.010 & 0.114 & 0.012 \\
\hline
\end{tabular}


Fig.1 Effect of cube size, polythene gauges and vacuum on minimally processed potato cubes (end of storage i.e. $2^{\text {nd }}$ day)

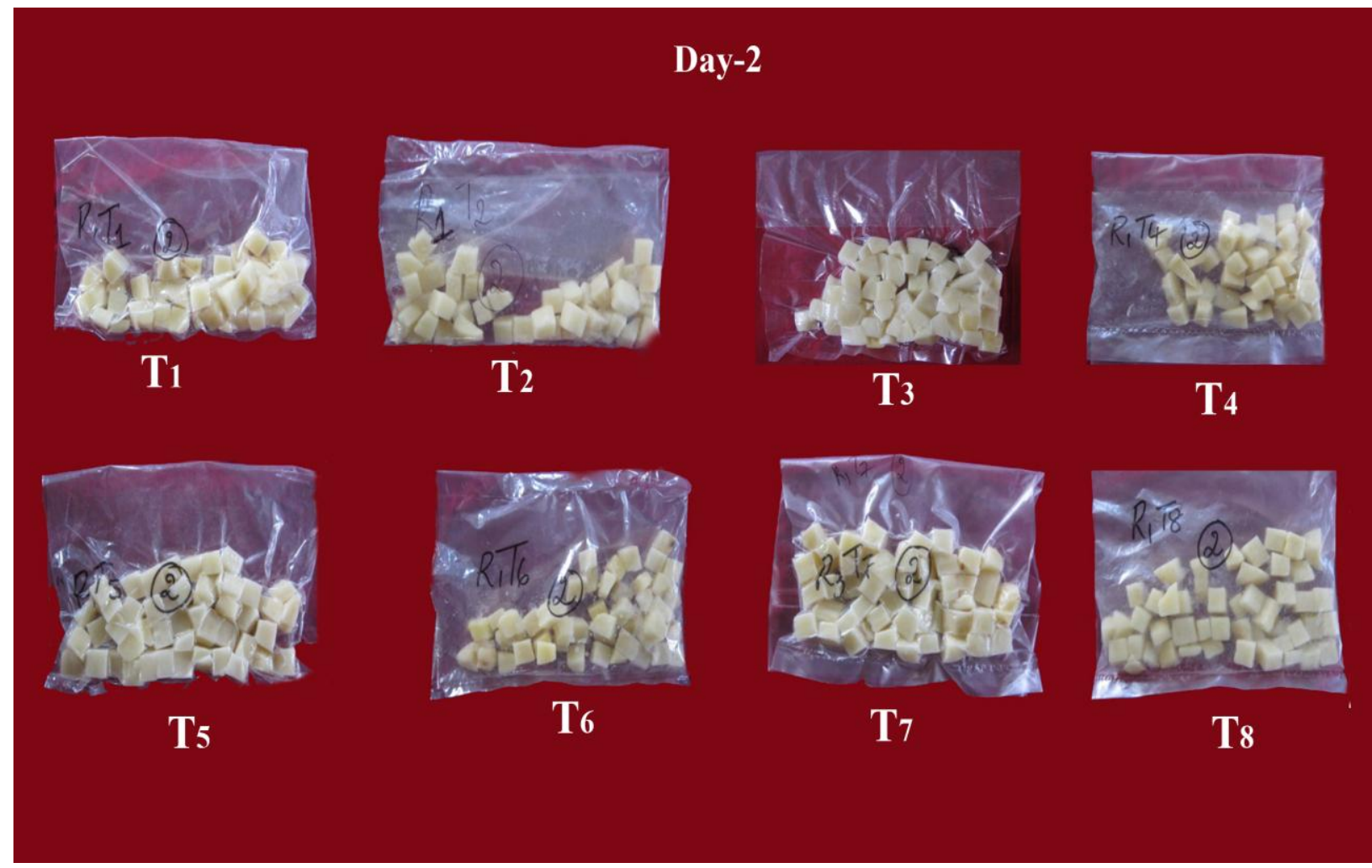

Highest organoleptic score (5) $\mathrm{T}_{7}\left(2 \mathrm{~cm}^{3}\right.$ cube packed in 200 gauge polyethylene bag with vacuum) and $\mathrm{T}_{3}\left(1 \mathrm{~cm}^{3}\right.$ cube packed in 200 gauge polyethylene bag with vacuum) compared to the all other treatments. The higher scores in above treatments might be attributed to the fact that, cubes maintained good quality by avoiding the microbial infection, rotting, their by retained of good quality at the end of storage period. The lower scores might be due to the higher microbial infection, rottage and spoilage of cubes and formation of secondary metabolites finally affecting organoleptic properties of the products. Similar results were obtained by Ezekiel and Manju Rani (2005) who opined that some of compounds may be evanescent, resulting in poor organoleptic score in control at the end of storage period.
Maximum shelf life was recorded in $\mathrm{T}_{7}(2$ $\mathrm{cm}^{3}$ cube packed in 200 gauge polyethylene bag with vacuum) which was on par with $\mathrm{T}_{5}$ $\left(2 \mathrm{~cm}^{3}\right.$ cube packed in 100 gauge polyethylene bag with vacuum) this might be due to lightness factor of vacuum packed potatoes was almost constant in vacuum packaging compared to potatoes packed without vacuum. Similar results were found in Desiree variety of potato by Rocha et al., (2003) and Chassery and Gormley (1994).

In conclusion, minimally processed fresh cut potato cubes are a basic ingredient for ready to use vegetable and it is having increasing demand and success in the market. These minimally processed cut potatoes are highly susceptible to browning which was unaesthetic to consumers and processors. therefore it is very important to find 
parameters to enhance the shelf life of minimally processed potato. By the present investigation, i.e., effect of cube size, polythene gauge and vacuum on physical characteristics of minimally processed potato it was concluded that minimally processed potato, $2 \mathrm{~cm}^{3}$ cube sizes, 200 gauge polythene bag and with vacuum packaging recorded better quality parameters as compared to the 1 $\mathrm{cm}^{3}$ cube sizes, 100 gauge polythene bag and without vacuum packaging.

\section{References}

Anderson, E.E., and Zapsalis, C. 1957. Technique ups quality, shelf-life of prepeeled potatoes. Food Eng. 26(2): 114116.

Balasubramanyam, N., and Anandswamy, B. 1979. Packaging requirements for fried potato chips. Indian Food Packer.3: 3-7.

Brackett, R.E. 1987. Microbiology consequences of minimally processed fruits and vegetables. Journal of Food
Quality. 19: 195-206.

Ezekiel, R., and Manju, R. 2005. Effect of predehydration chemical treatment on enzymic discolouration and rehydration of solar dehydrated potato slices and cubes. Potato Journal. 33(3):104-109.

Rocha, A.M.C.N., Coulon, E.C., and Morais, A.M.B. 2003. Effects of vacuum packing on physical quality of minimally processed potatoes. Food Service Technology. 3(2): 81-88

Sagar, V.R., and Roy, S.K. 1997. Studies on packaging and storage of potato powder. Indian Food Packer. Pp. 67.

Sandhu, K.S., and Parhawak, B. 2002. Studies on the preparation of dehydrated potato cubes. Journal of Food Science \& Technology. 39(6): 594-602.

Watada, A. E., Abe, K., and Yamauchi, N. 1990. Physiological activities of partially processed fruits and vegetables. Food. Technology. 44(5):116-122.

\section{How to cite this article:}

Shireesha, P., R. Rajya Lakshmi, M. Rajashekar and Paratpara Rao, M. 2018. Effect of Cube Size, Polythene Gauge and Vacuum on Physical Characteristics of Minimally Processed Potato. Int.J.Curr.Microbiol.App.Sci. 7(12): 2075-2079. doi: https://doi.org/10.20546/ijcmas.2018.712.237 